searches to five national patent offices. But last year, in a move that helped trigger the current dispute, the EPO council decided that its examiners should do both the search and the examination on each application.

A second cause of the row was the Finnish patent office's decision to apply for Patent Cooperation Treaty status, to allow it to conduct searches for those considering filing patents to, for example, the US and Japanese offices. There is nothing to stop a European nation from doing this - but none had chosen to do so since the EPO was established in 1973.

Since then, all hell has been let loose inside the administrative council. Decentralizers want more of the action to be devolved, and maintain that their staff can readily match EPO quality.

\section{On the edge}

Lars Björklund, deputy director-general of the Swedish patent office, argues that countries on the geographical edge of Europe need to maintain their own expertise in intellectual property to support local inventors. "And we could help with the EPO's backlog," he says.

But Wim van der Eijk, EPO head of international relations, charges that those backing decentralization "are trying to reverse history". EPO officials claim that quality will suffer: McGinley says that the office would have liked to complain to the administrative council about the quality of searches carried out by two of the five national offices that had earlier shared EPO work. But it proved politically impossible to do so, because the relevant offices were represented on the council. "Everything quickly becomes politicized," he says. "You can put whatever quality control you want in place - you just can't enforce it."

The EPO is instead trying to win delegations over to a plan that it hopes will meet concerns that they might lose their expertise. Its proposed 'utilization programme' incorporates things such as training in all aspects of intellectual property, and building computer systems that providse national patent offices with full access to EPO documentation and software, such as that used to do searches.

The office is reconciled to negotiations beyond next month's meeting before the issue is resolved. In the meantime, users remain bemused. "I see no rationale other than political for splitting the office's work," says Stein.

London-based patent attorney Richard Jackson of Carpmaels and Ransford, a computing specialist whose customers include University College London, says: "The quality of EPO work is good. I'd have thought that outsourcing would be the last thing it needs right now."

\section{IN BRIEF}

LIFT OFF OR RIP-OFF? Qinetiq, the UK technology company built from the research laboratories of the country's ministry of defence, successfully floated on the London stock exchange on 13 February (see Nature 436,$775 ; 2005$ ). Shares in the company closed up $6 \%$ on the opening day's trading at $E 2.12$ (US\$3.68), valuing the company at $£ 1.3$ billion. But the British government has been sharply criticized for its handling of the privatization, under which the Washington-based Carlyle group took a minority stake in the company in $\mathbf{2 0 0 2}$ and fattened its value through the acquisition of several US defence contractors, before realizing an eight-fold return on its initial investment of €42 million.

SUCCESSION STRUGGLE SkyePharma's board of directors has ousted the company's founder and chairman, in an attempt to clear the way for the man it earlier this month appointed to succeed him. The board installed Jerry Karabelas, a former chief executive of Novartis' drug division, to replace lan Gowrie-Smith. However, it must win shareholders' approval of the appointment at an extraordinary general meeting that will be held in the next few weeks. Dissident shareholders in the London-based drug delivery firm are backing Bob Thian, current head of laboratory-supplies company Whatman, for the job.

AVASTIN SETBACK Enrollment in a clinical trial of Genentech's blockbuster cancer drug, Avastin, has been suspended because of non-cancer-related deaths in one group of patients taking the drug. The company said that seven people with early-stage colon cancer, some of them young, died in a group that was taking Avastin in addition to standard chemotherapy; two of these patients died of cardiac causes. In a group of patients on standard chemotherapy alone, four died from non-cancer causes. Sales of Avastin in the United States last year were $\$ 1.1$ billion.

\section{MARKET WATCH}

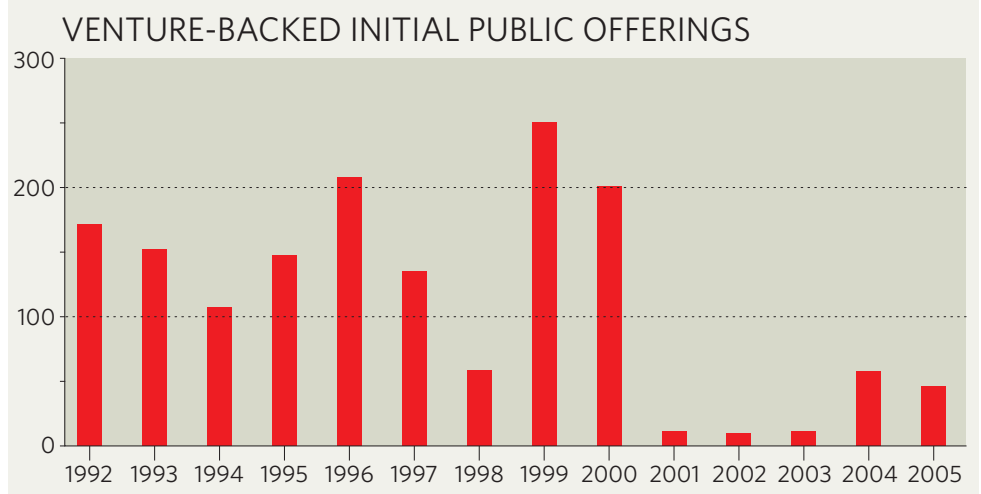

The number of initial public offerings for US companies that had been backed by venture capital fell back during 2005, and shows little sign of returning to its 1990s levels.

Low investor interest, together with regulatory changes on Wall Street that have made it more complicated and expensive for companies to obtain a public listing, have made it more likely that venture capitalists will get their money back by selling young companies directly to large corporations, analysts say.

The number of public offerings fell from 67 in 2004 to just 41 last year, according to data compiled by research firm VentureOne, a San Franciscobased unit of Dow Jones. This is sharply down, not just on the days of the dot.com boom, but also on the regular level of such offerings in the years before then (see graph).

VentureOne research analyst Josh Grove points out that corporations have no shortage of cash available to make such acquisitions. Last year, they forked out more than $\$ 27$ billion to make them happen, up almost one-fifth on 2004.

"They're snapping up these companies before they can go public," he says.

Thirteen of last year's offerings were biotechnology firms and 11 specialized in information technology. In biotechnology, investors have become particularly wary of buying into companies until they are running latestage clinical trials. "The demand is not there," says Michael Lytton, a general partner of Oxford Bioscience Partners, a life-sciences venture capital company based in Boston.

Helen Pearson 